\title{
Lypsykarjatilojen yksikkötuotantokustannuksen muutos
}

\author{
Alina Sinisalo \\ MTT Taloustutkimus, Latokartanonkaari 9,00790 Helsinki, alina.sinisalo@mtt.fi
}

\section{TIIVISTELM}

Lypsykarjatilojen määrä on vähentynyt $57 \%$ vuodesta 2000 vuoteen 2012, mutta lehmien lukumäärä vain $22 \%$. Vuonna 2000 lypsykarjatiloilla oli keskimäärin 15,9 lehmää, kun taas vuonna 2011 lehmiä oli 26,9. Tässä tutkimuksessa selvitettiin lypsykarjatilojen tuotantokustannusten muuttumista MTT:n kannattavuuskirjanpitotoimintaan osallistuvilla lypsykarjatiloilla 2000-2011. Tuotantokustannuksia tarkasteltiin yksikkötasolla siten, että lypsykarjatilan kokonaistuotantokustannukset jaettiin tuotetulla maitomäärällä (c/l). Tutkimusaineisto oli paneelimuotoinen kirjanpitoaineisto, joka mahdollisti tilojen välisten erojen huomioimisen, kun niiden ominaisuudet muuttuivat aikajaksolla 2000-2011. Aineistossa oli yhteensä 4205 havaintoa ja 633 tilaa. Kustannukset deflatoitiin kuluttajahintaindeksillä vuoden 2011 tasoon. Tarkastelut tehtiin lineaarisella sekamallilla.

Kuvailevan tarkastelun mukaan tuotantokustannus oli 2000-2011 keskimäärin 99,9 c/1. Vuodesta 2000 vuoteen 2011 mennessä tuotantokustannus pienentyi noin 7\%. Tuotantokustannus on vaihdellut eri tukialuilla. A-, C1- ja C2-tukialueilla tarkastelujakson keskimääräinen tuotantokustannus oli lähestulkoon sama (95,5 c/1, 96,2 c/1 ja 96,7 c/1, vastaavasti). Tukialueilla B ja C2P-C4 tuotantokustannus oli 108,6 c/1 ja 106,3 c/1 (tutkimuksessa tukialueet C2P, C3 ja C4 yhdistettiin). Tarkasteltaessa tuotantokustannusta tilojen kokoluokkien (luokittelu standardituotoksen perusteella) mukaan, havaittiin pienillä tiloilla (standardituotos alle $50000 €$ ) selvästi keskisuuria $(50000-100000 €$ ) ja suuria (yli $100000 €)$ kokoluokkia suurempi kustannustaso. Myös kustannusten vuotuinen vaihtelu oli pienillä tiloilla suurempaa.

Mallin tulosten perusteella tilojen tuotantokustannusten vuosien välinen korrelaatio on suuri $(0,492 ; p<0,001)$. Kustannukset muuttuvat tiloilla ajan kuluessa eri nopeudella $(p<0,020)$. Mallissa aikamuuttujan vaikutus $(1,485 ; \mathrm{p}<0,001)$ on kaksinkertainen lehmämäärän vaikutukseen $(-0,708$; $\mathrm{p}<0,001)$ verrattuna. Tulos voidaan tulkita niin, että tilaa pitäisi kasvattaa vuosittain kahdella lehmällä, jotta voitaisiin kompensoida vuotuinen ajan kuluessa tapahtunut kustannusten kasvu. Tukialue selittää heikosti tuotantokustannusten eroja. Vain B-tukialue erottuu pohjoisimmista tukialueista $(\mathrm{C} 1, \mathrm{C} 2 \mathrm{ja}$ $\mathrm{C} 2 \mathrm{P}-\mathrm{C} 4)$ siten, että B-alueella on muita tukialueita suurempi kustannus. Mallin mukaan pienin kokoluokka eroaa muista kokoluokista merkitsevästi $(\mathrm{p}<0,001)$ siten, että yksikkökustannukset ovat suuremmat pienillä tiloilla. Keskisuuri ja suuri kokoluokka eivät eroa toisistaan merkitsevästi $(p=0,161)$.

Asiasanat: lypsykarjatilat, yksikkökustannus, lehmä, alue, kokoluokka 


\section{Johdanto}

Suomen maataloudessa on käynnissä voimakas rakennemuutos, jonka vaikutusta maatalouden tuotantokustannuksiin on tutkittava huomioiden pitemmän aikavälin muutokset. Tutkimuksessa selvitettiin lypsykarjatilojen tuotantokustannuksia aikavälillä 2000-2011. Lypsykarjatilojen määrä on vähentynyt 57\% vuodesta 2000 (22 913 tilasta) vuoteen 2012 (9 781 tilaan), mutta lehmien lukumäärä vain 22\% (kuva 1). Vuonna 2000 lypsykarjatiloilla oli keskimäärin 15,9 lehmää, kun taas vuonna 2011 lehmiä oli 26,9 .

Tuotantokustannukset ovat kasvaneet koko 2000-luvun ajan kaikissa tuotantosuunnissa. Siten myös lypsykarjatilojen tuotantokustannukset ovat kasvaneet (111\%). Kustannusten kasvu on osittain johtunut myös tilakoon kasvusta. Lypsykarjatilojen kustannukset ovat kasvaneet kuitenkin tilakokoa nopeammin (Sinisalo \& Niemi, 2013).

Kuvassa 2 on esitetty lypsykarjatilojen tuotantokustannusten kehitys kustannuslajeittain. Kokonaistuotantokustannus on summa seuraavista kustannuslajeista: tarvike-, kotieläin-, kone-, rakennus-, työ- ja korkokustannus sekä muu kustannus. Tarvikekustannuksiin sisältyvät lannoitteet, kalkitus, siemenet, kasvinsuojelu, polttoaineet, sähkö ja ostorehut. Kotieläinkustannuksiin sisältyvät eläintenostokulut ja muita kotieläimiin liittyviä kustannuksia, kuten eläinlääkkeet, kotieläinten tarvikkeet, eläinlääkärikulut ja siemennyskulut. Konekustannuksiin sisältyvät konepoistot ja muita koneisiin liittyviä kustannuksia, kuten kunnossapito, vuokraus, kalustohankinta. Rakennuskustannus muodostuu rakennuspoistoista ja muista rakennuskustannuksista. Muu kustannus pitää sisällään vakuutukset, kiinteät vuokrat, peltovuokran, muut poistot ja muita kustannuslajeja. Työkustannus koostuu maksetuista palkoista ja yrittäjän palkkavaatimuksesta. Palkkavaatimus on yrityksen työkirjanpitoon perustuva yrittäjäperheen työtuntimäärä kerrottuna ennalta asetetulla tuntipalkkavaatimuksella, jota on muutettu vuosittain maataloustyöntekijän tuntipalkan muutoksen mukaisesti. Korkokustannus koostuu korkokuluista ja oman pääoman korkovaatimuksesta.

Tämän tutkimuksen tavoitteena oli tutkia lypsykarjatilojen yksikkötuotantokustannusten muuttumista 2000-luvulla ottaen huomioon tilakohtaiset tiedot ja aikatrendin vaikutus.

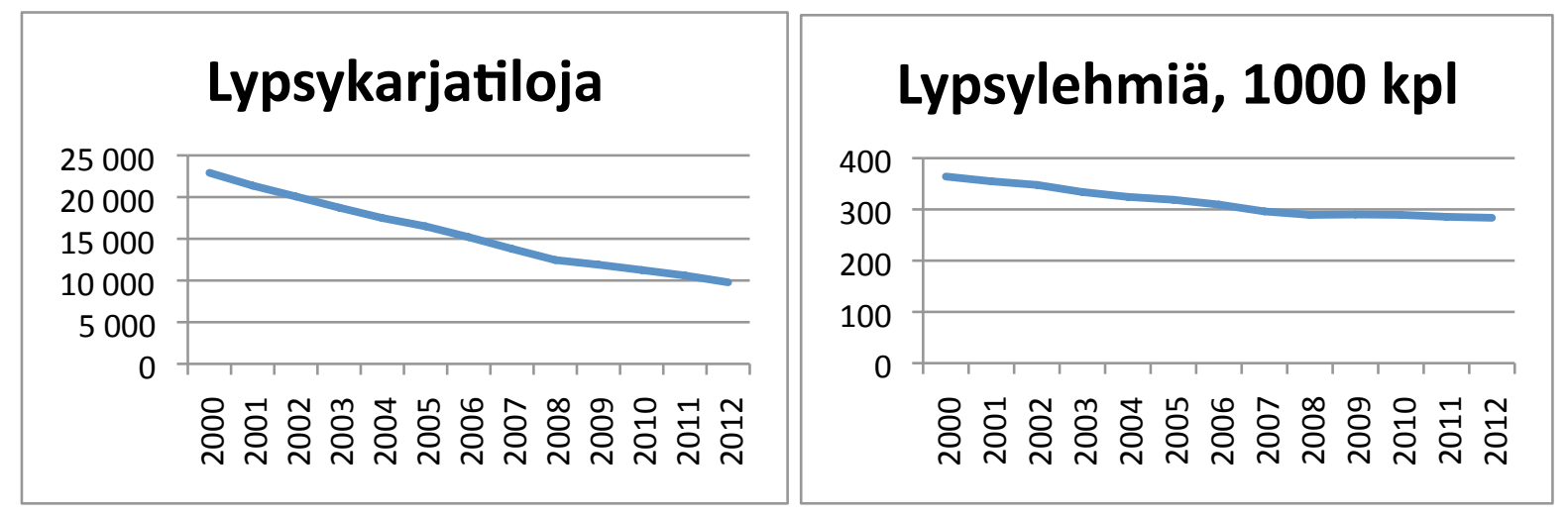

Kuva 1. Lypsykarjatilojen ja lypsylehmien lukumäärä vuosina 2000-2012 (Tike). 


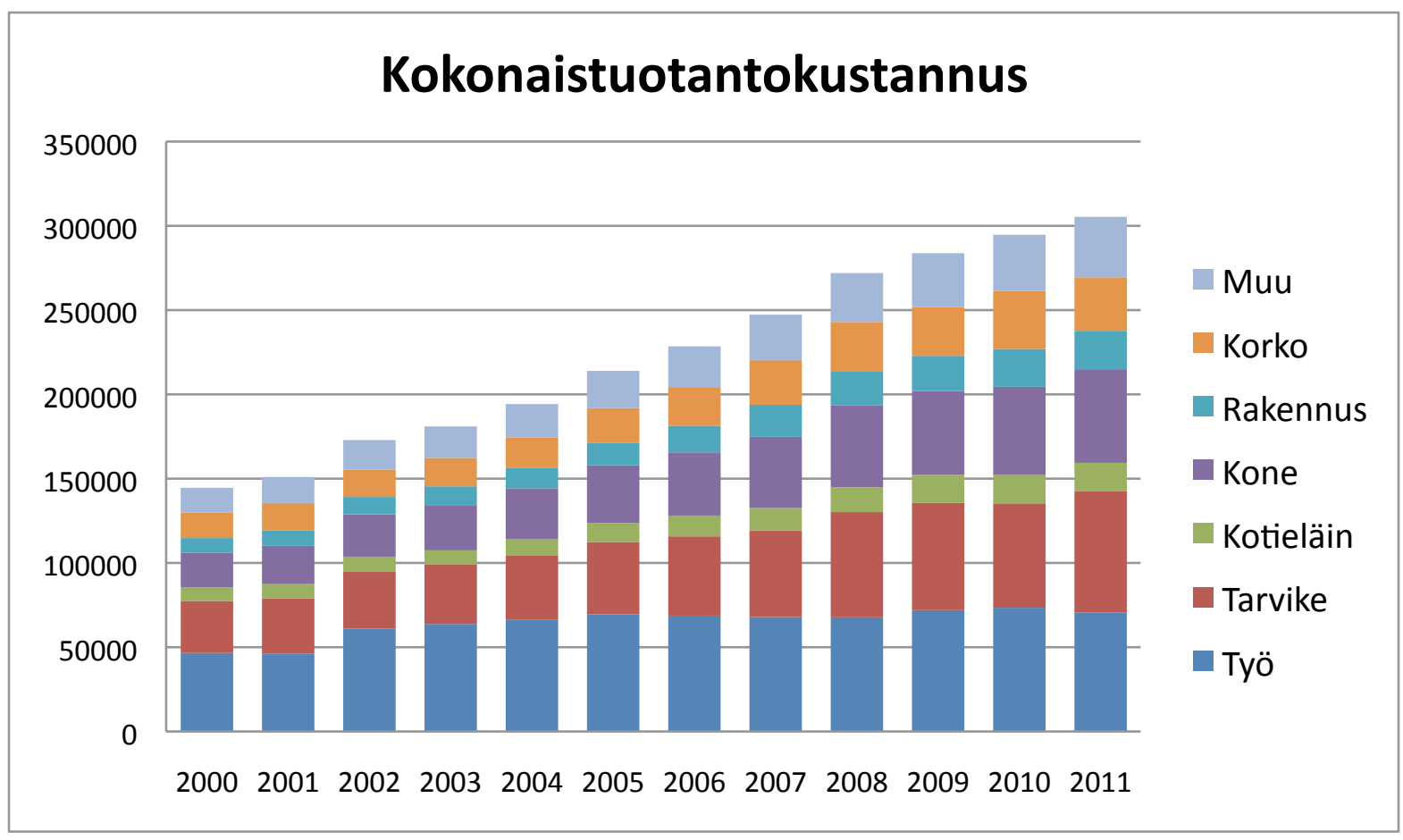

Kuva 2. Keskimääräisten kokonaistuotantokustannusten rakenteen kehitys 2000-2011 kirjanpitotiloilla. Vuoden 2011 hinnat.

\section{Aineisto ja menetelmät}

Lypsykarjatilojen tuotantokustannusten muuttumista tutkittiin käyttäen MTT:n kannattavuuskirjanpitotoimintaan osallistuvien lypsykarjatilojen tietoja vuosilta 2000-2011. Aineisto on muodoltaan paneeli. Toistomittaukset yrityksistä on tehty vuoden välein. Tarkasteluvälillä 2000-2011 osa yrityksistä on poistunut vapaaehtoisesti kannattavuuskirjanpitotoiminnasta, osa on lopettanut toimintansa ja osa tullut mukaan kesken tarkastelujakson. Paneeliaineisto ei ollut siis täydellinen (unbalanced panel data). Tarkastelussa on ollut yhteensä mukana 4205 havaintoa ja 633 eri tilaa; keskimäärin 350 tilaa joka vuosi.

Tuotantokustannuksia tarkasteltiin yksikkötasolla siten, että lypsykarjatilan kokonaistuotantokustannukset jaettiin tuotetulla maitomäärällä (c/l). Tutkimuksen yksikkötuotantokustannus ei siis ole erityisesti maidontuotantoon liittyvä kohdennettu, vaan mukana on myös maitotilojen muihin maataloustuotteisiin liittyvät kustannukset, mitä lypsykarjatiloilla ovat enimmäkseen naudanlihan tuotantoon liittyviä kustannuksia.

Tilojen tuotantokustannukset deflatoitiin kuluttajahintaindeksillä (SVT 2013) vuoden 2011 tasoon. Tarkastelut tehtiin lineaarisella sekamallilla. Mallissa huomioitiin tilojen väliset erot, kun yritysten ominaisuudet muuttuivat tarkastelujaksolla 2000-2011. Malliin sisällettiin kiinteät vaikutukset ja satunnaisvaikutukset. Satunnaisvaikutusten kovarianssirakenteeksi valittiin rakenteeton malli (UN), joka soveltuu pitkittäisaineistoihin. Jäännösvaihtelulle valittiin ensimmäisen asteen autoregressiivinen rakenne (AR1), koska se soveltuu hyvin aineistoon, jossa samasta havaintoyksiköstä on otettu peräkkäisiä havaintoja ja voidaan olettaa, että lähekkäin olevat havainnot korreloivat keskenään voimakkaammin kuin kaukana toisistaan otetut havainnot. Yleensä mikä tahansa tuotanto edellyttää kiinteää tuotantopanoksista riippumatonta kustannusosaa, joten malliin sisällettiin myös vakiotermi.

\section{Tulokset ja tulosten tarkastelu}

Kuvailevan tarkastelun mukaan yksikkötuotantokustannus oli vuosina 2000-2011 keskimäärin 99,9 c/1. Vuodesta 2000 vuoteen 2011 mennessä yksikkötuotantokustannus pienentyi noin 7\%.

Tuotantokustannus on vaihdellut eri tukialuilla. A-, C1- ja C2-tukialueilla tarkastelujakson keskimääräinen tuotantokustannus oli lähestulkoon sama $(95,5 \mathrm{c} / 1,96,2 \mathrm{c} / 1$ ja 96,7 c/l, vastaavasti). Tukialueilla B ja C2P-C4 tuotantokustannus oli 108,6 c/l ja 106,3 c/l (tutkimuksessa tukialueet C2P, C3 ja $\mathrm{C} 4$ yhdistettiin). 
Tarkasteltaessa tuotantokustannusta tilojen kokoluokkien (luokittelu standardituotoksen perusteella) mukaan, havaittiin pienillä tiloilla (standardituotos alle $50000 €$ ) selvästi keskisuuria (50 000$100000 €$ ) ja suuria (yli $100000 €$ ) kokoluokkia suurempi kustannustaso. Myös kustannusten vuotuinen vaihtelu oli pienillä tiloilla suurempaa.

Mallin tulosten perusteella tilojen tuotantokustannusten vuosien välinen korrelaatio on suuri $(0,492 ; p<0,001)$. Kustannukset muuttuivat tiloilla ajan kuluessa eri nopeudella $(p<0,020)$. Mallissa aikamuuttujan vaikutus $(1,485 ; \mathrm{p}<0,001)$ on kaksinkertainen lehmämäärän vaikutukseen $(-0,708$; $\mathrm{p}<0,001)$ verrattuna. Tulos voidaan tulkita niin, että tilaa pitäisi kasvattaa vuosittain kahdella lehmällä, jotta voitaisiin kompensoida vuotuinen ajan kuluessa tapahtunut kustannusten kasvu. Tukialue selittää heikosti tuotantokustannusten eroja, sillä vain B-tukialue erottuu pohjoisimmista tukialueista $(\mathrm{C} 1, \mathrm{C} 2$ ja $\mathrm{C} 2 \mathrm{P}-\mathrm{C} 4)$ siten, että $\mathrm{B}$-alueella on muita tukialueita suurempi kustannus. Mallin mukaan pienin kokoluokka eroaa muista kokoluokista merkitsevästi $(\mathrm{p}<0,001)$ siten, että yksikkökustannukset ovat suuremmat pienillä tiloilla. Keskisuuri ja suuri kokoluokka eivät eroa toisistaan merkitsevästi $(p=0,161)$.

Tarkasteltaessa yksikkötuotantokustannuksia tuotantohaaraan kohdennettuna Latukka (2013) ei myöskään havainnut merkittäviä eroja eri tukialueiden välillä. Tilakoon suhteen Latukka (2013) havaitsi, että pienillä tiloilla (10 lehmää) yksikkökustannus on merkittävästi suurin (119 c/l) ja lehmämäärän lisääntyessä yksikkökustannukset pienenevät. Keskikokoisilla 39 lehmän tiloilla yksikkökustannus on noin $76 \mathrm{c} / 1$ ja suurilla 141 lehmän tiloilla $69 \mathrm{c} / 1$. Esimerkkitilakokojen valinta oli tehty standardituotokseen perustuen, että lehmämäärä oli kunkin luokan keskiarvo.

\section{Johtopäätökset}

Lypsykarjatilojen kokonaistuotantokustannukset ovat olleet kasvussa koko 2000-luvun ajan, mutta kustannukset suhteutettuna tuotettuihin maitolitroihin ovat pienentyneet. Mittakaavaetuja on ollut saavutettavissa. Tuotantokustannusten muutokset ovat olleet erilaiset eri tiloilla.

\section{Kirjallisuus}

Latukka, A. 2013. Mitä maitolitran tuottaminen maksaa? Kustannusrakenteen tuntemus auttaa kehittämään kannattavuutta. Maito ja Me 3/2013, sivut 50-51.

Sinisalo, A. \& Niemi, J. 2013. Kustannusten nousu kurittanut kotieläintiloja 2000-luvulla. KM 11/2013, sivut 40-41.

Suomen virallinen tilasto (SVT). 2013. Kuluttajahintaindeksi (verkkojulkaisu). ISSN 1796-3524. Helsinki: Tilastokeskus. Saatavilla: http://www.stat.fi/til/khi/index.html.

Tike. Maa- ja metsätalousministeriön tietopalvelukeskus. Maatilojen rakenne, Kotieläinten lukumäärä. 